\title{
THE EFFECT OF SPORT MOTIVATION ON PERCEPTION OF RISK
} AND UNCERTAINTY ${ }^{1}$

\section{SPORDA GÜDÜLENMENIN RİSK VE BELIRSSIZLIIK ALGISINA ETKİSİ}

\author{
Meltem PAKSOY', Fehmi ÇALIK ${ }^{2}$, Ilimdar YALÇIN ${ }^{3}$ \\ ${ }^{1}$ Abdullah Gul University, Internal Auditor, Kayseri / Turkey \\ ${ }^{2-3}$ Sakarya University, Faculty of Sports Sciences, Sakarya / Turkey
}

Öz: Hızla değișen dünyamızda örgütler, girișimci, belirsizliğe tolerans gösterebilen, risk alan ve yeniliklere açık bireylere ihtiyaç duymaktadır. Yapılan araştırmalarda, spor yapan bireylerin risk alma düzeyleri değerlendirildiğinde spor yapmayan bireylere oranla daha yüksek puanlara sahip olduğu anlaşılmıştır. Yapılan araştırmada sporda içsel güdülenmenin bireylerin risk ve belirsizlik algısına etkisi ile aralarındaki ilişki araştırılmıştır. Araştırmada basit tesadüfi örnekleme yöntemiyle belirlenen Erciyes Üniversitesi Beden Eğitimi ve Spor Yüksekokulu öğrencilerinden günlük hayatları içinde spora yer veren 218 kişiye yüz yüze görüşme yöntemiyle anket uygulanmıştır. Araştırma modeline göre geliştirilen hipotezler uygun istatistiksel yöntemlerle analiz edilmiştir. Yapılan çalışmada aşağıda belirtilen sonuçlara ulaşılmıştır: Sporda içsel boyutta güdülenen bireylerin risk ve belirsizlik algı düzeyleri arasında pozitif, doğrusal ve orta düzeyde bir ilişki bulunmaktadır. Sporda içsel güdülenme bireylerin risk ve belirsizlik algısı üzerinde etkilidir

Anahtar Kelimeler: Motivasyon, Risk, Belirsizlik, Risk Algisı
Abstract: In our rapidly changing world, organizations need individuals who are entrepreneur and open to innovations, can tolerate uncertainty and take risks. In conducted studies, it is concluded that, as risk taking levels of individuals who actively are in sports are evaluated, they have higher scores of risk taking than individuals who do not do sports have. The effect of sport motivation on individuals' perception of risk and uncertainty and the relationship between them were researched in the research. Face to face survey was administered to 218 people, who involve sports in their daily lives, selected by simple random sampling method among the students of School of Physical Education and Sports of Erciyes University. Hypotheses which have been developed according to research model were analyzed by appropriate statistical methods. Below are the results of the research conducted: There is a positive, linear and moderate relationship between perceived levels of risk and uncertainty in individuals who are intrinsically motivated in sports. Intrinsic motivation in sports is influential on individuals' risk and uncertainty perceptions.

Key Words: Motivation, Risk, Uncertainty, Risk Perception

Doi: $10.17363 /$ SSTB.20162124010

(1) Corresponding Author: Meltem PAKSOY, Abdullah Gul University, Internal Auditor, İstanbul Turkey meltem. paksoy@agu.edu.tr. Received: 02.09.2016 Date of Arrangement 11.10.2016 Accepted: 19.11.2016 Type ofarticle (Research -Application) Conflict of Interest: None / "None of Ethics Committee" 


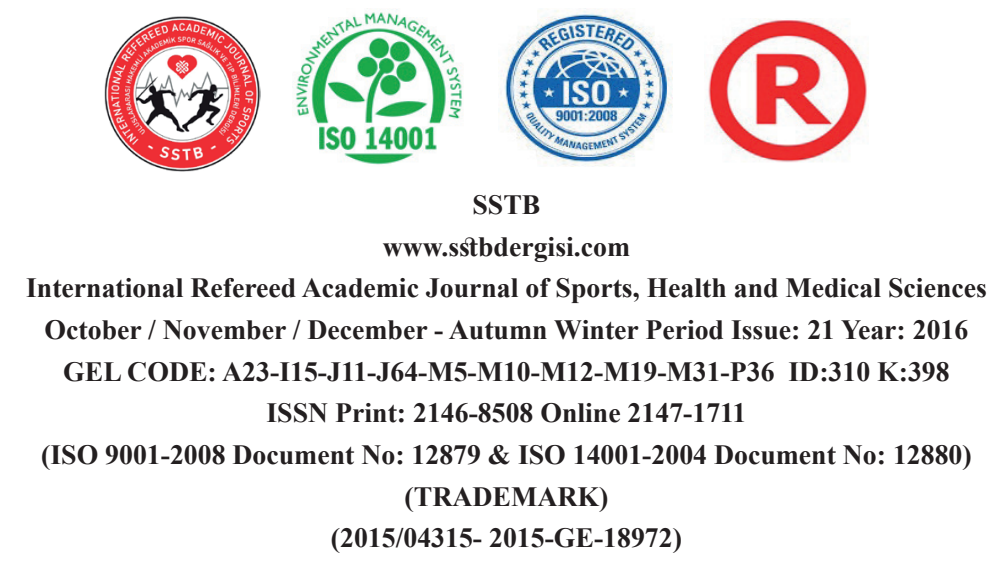

\section{INTRODUCTION}

The term motivation comes from the word "movere" and means to move. It has many different definitions. Wang (2004) as "complete internal mechanisms and external stimulants which direct behaviors" (Wang, 2004: 517)"; Franken (1994) as "stimulation, way and continuation of behavior” (Başer, 1998; Franken, 1994; Erdem, 2008: 7) and Eren (2015) as “individuals' behaving and striving intentionally for achieving a goal". Although there are a number of different definitions in literature, they generally have a common point which is an internal desire's prompting individuals and directing their behaviors. A number of theories have been suggested about motivation. According to one of these theories, namely, Self Determination Theory by Deci \& Ryan (2000), motives have a multidimensional structure and emerge in the ways intrinsic motivation, extrinsic motivation and amotivation to various extent (Deci \& Ryan, 2000: 231). Extrinsic motivation emerges through other humans with positive and negative supports (Danışman, 2011: 11). It is utterance of environmental press and desires. Amotivation describes lack of an intrinsic motive for behaving and as a result, non-formation of behavior (Mumcu, 2011: 40). Amotivated individuals cannot be motivated both intrinsically and extrinsically (Deci \& Ryan, 2000: 232). In intrinsic motivation, the source is individual's behaviors. External factors do not affect continuation of these behaviors. Thereafter, Vallerand and his friends suggested that intrinsic motivation has three subcategories which are knowledge, accomplishment and experiencing stimulation (Vallerand and Losier, 1999; Vallerand et all, 1987; Vallerand and Bissonnette, 1992: 601). The highest end of Self Determination Theory stems from intrinsic motivation. Individuals' behaviors in such a situation are intrinsic behaviors which are independent of physical rewards or external press (Ersöz et al, 2012: 18). Intrinsic motivation means individuals' behaviors to participate in an activity with their free will without another person or thing (Kazak Çetinkalp, 2009: 12). According to Cox (1998), intrinsic motivation is the same with motive to accomplish. Researchers indicate that intrinsic motivation causes sportsmanship and motivation at higher degrees for beginners in sports (Bakker et al, 1990; Wang, 2004: 518). Perception is the process in which individuals choose information input, organize it and interpret it in order to create a meaningful world image (Kotler et all, 2000). Is there a common point between perception levels of intrinsically motivated individuals in sports and their personalities? How do they act against risk and uncertainties? To answer these questions, the term risk must be primarily explained. 


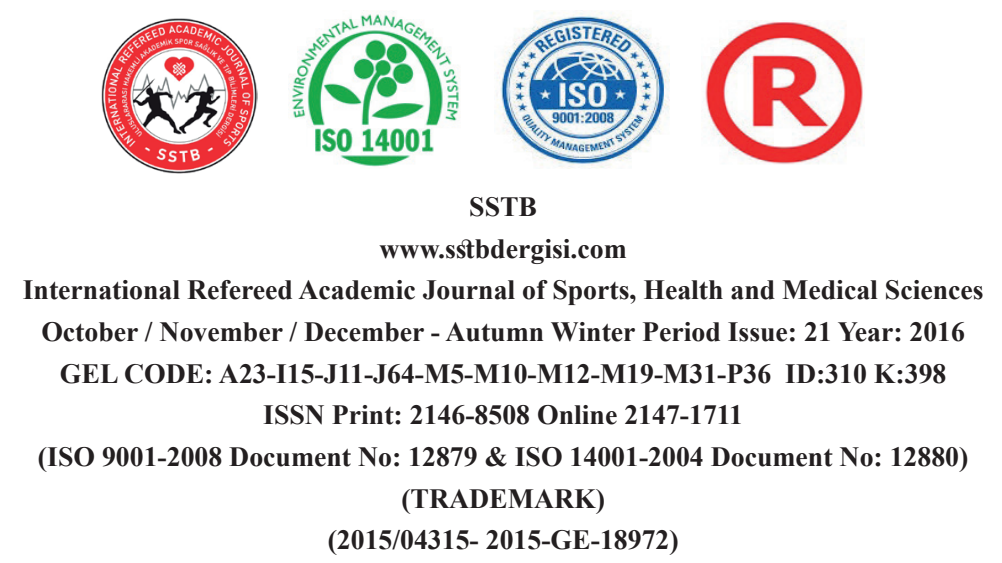

According to Willet (1971), risk is uncertainty of an undesired event to occur. It can also be defined as the probability of an undesired event in the future (Willet, 1971: 471). Risk is the uncertainty related to possible effects after performing decisions. This uncertainty means that outcomes of decisions may create disappointment (Sitkin and Paolo, 1992: 26). The terms risk and uncertainty are related but not the same terms. Risk is the rate of probability of an event whereas uncertainty is the expectation of anything independently of any probability and it causes worry. It has both negative and positive components. While negative components of uncertainty contain several risks, positive ones contain opportunities (Y1lmaz, 2005: 28). Tolerance for uncertainty which is one of the most important characteristics of entrepreneur individuals can be defined as the ability to react positively to uncertain situations (Erdem, 2001: 48). According to Furedi (2001), risk is associated with how individuals or society describe themselves in changing and coping with the future. Risk is commonly known as a dangerous term and indicates the events expected to occur in the future but not certain (Özer and Gülpınar, 2005: 50). However, risk can also contain opportunity besides representing an undesired event and danger. Opportunity is the probability of occurrence of something helpful to achieve goals. Opportunities help to create and protect values and they create benefits. Risk and benefit are related to each other (Finucane et all, 2000: 8). In the world which changes rapidly and shows a dynamic structure, tolerance for uncertainty, risk taking and innovativeness are among the features which organizations need in entrepreneurs (Tabak et al, 2010). In conducted studies, it is concluded that, as risk taking levels of individuals who actively are in sports are evaluated, they have higher scores of risk taking than individuals who do not do sports have (Mountaineers, 1975; Slanger \& Rudestam, 1997; Aktaş, \& Erhan, 2015: 41).

In literature review, it is seen that, in the research on sports and athletes, the term risk is approached as an undesired concept which affects athletes' performances negatively; sport organizations and athletes will be successful as they overcome risks. Undoubtedly, risk naturally contains negative, dangerous and undesired circumstances within itself. However, this loop is also within the concepts of opportunity and success. Risk on reasonable scales is one of the fundamental factors for success especially in business.

The concepts risk and motivation have been mentioned separately in various studies but they have not been in the same frame so much. In the research, the focus will be on the two concepts and the relationship between perception of risk and uncertainty of in- 


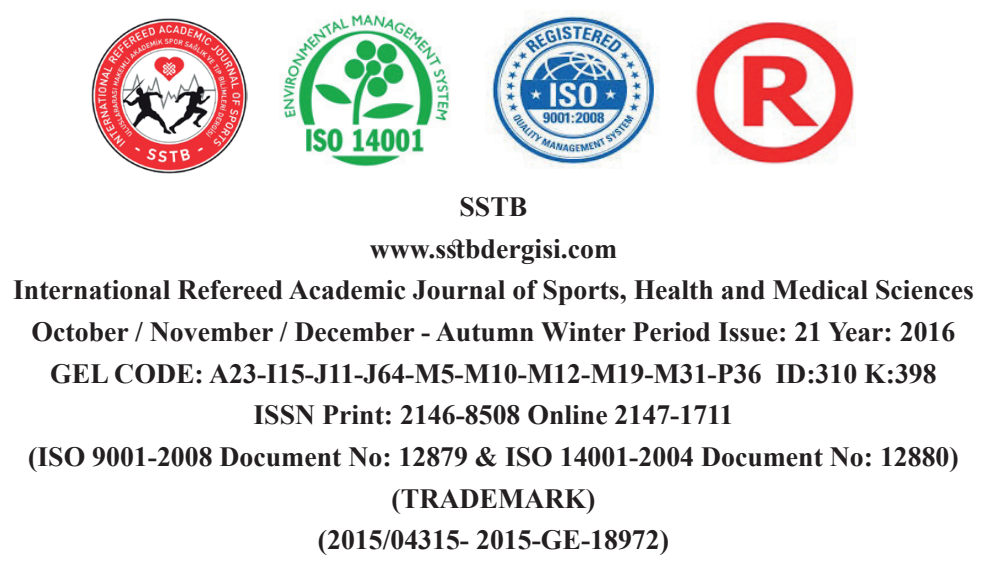

dividuals' intrinsically motivated in sports in their daily lives will be investigated.

Hypotheses which have been developed according to the purpose of the research in accordance with those stated above are as follows;

H1: There is a correlation between intrinsic motivation in sports and individuals' perception of risk and uncertainty.

$\mathrm{H} 2$ : Intrinsic motivation in sports has an effect on individuals' perception of risk and uncertainty.

\section{MATERIAL and METHODS}

\section{The Purpose of the Research}

In the conducted research, it was aimed to investigate the effect of sport motivation on perception of risk and uncertainty and whether there is a relationship between them.

\section{The Scope and the Method of the Research}

The sample of the research consist of the students from different departments of School of Physical Education and Sports of Erciyes University in 2015-2016 Academic Year. The sample was chosen by sample random sampling among the students of this school who involve sports in their daily lives and 218 students (97 females, 121 males) in total participate in the research.

\section{Data Collection}

In the research, descriptive research method and survey as the data collection tool which take part in quantitative research method are used. The survey is formed by three section. Personality and demographic characteristics in the first section, perception of risk and uncertainty in the second section and attitudes towards sport motivation in the third section are investigated.

Sport Motivation Scale (SMS), which was originally developed by Pelletier et al. (1995) according to Deci \& Ryan's (1985) Self Development Theory and whose preliminary examinations were made by Toros (2000) in our country and of which Kazak (2004) made validity and reliability studies, are used in the research in order to explain individuals' participation in sports, in which ways they are motivated to maintain this participation and which motives have the most influence on formation of behaviors. The scale is used only in intrinsic motivation because of its relation with the topic and not used in extrinsic motivation and amotivation. Participants were asked 12 questions in five point Likert scale $(1=$ Never; $5=$ Often). Four of these questions form the subscale experiencing stimulation and 8 form the subscales knowledge and accomplishment. Additionally, 6-question survey which was used in the article "Risk and Uncertainty Perceptions of Small Business 


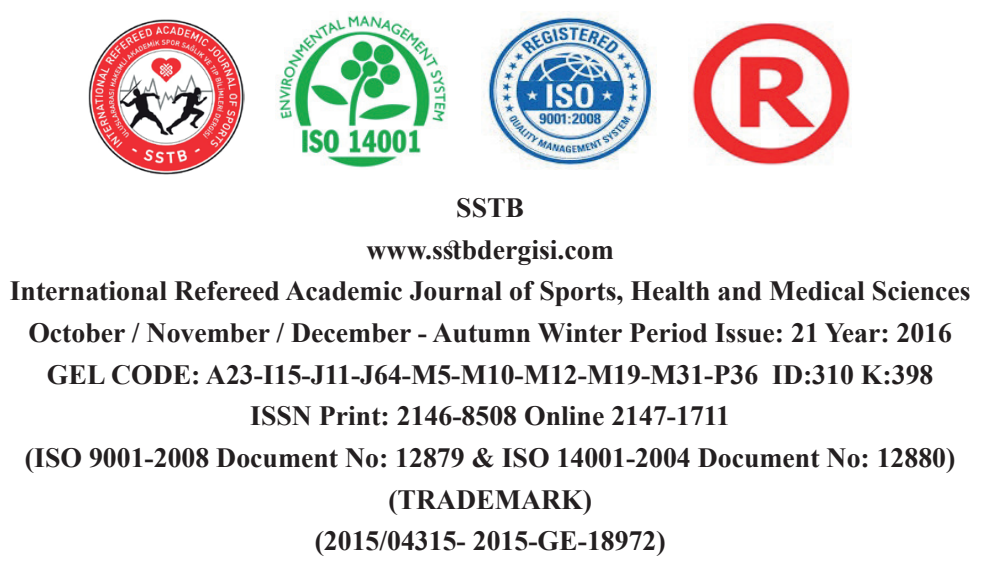

Entrepreneurship: A Case From Bursa" by Bozkurt and Baştürk (2003) over "Perception of Risk and Uncertainty" was applied. Participants were asked 6 questions in five point Likert scale $(1=$ Never; $5=$ Often $)$ about risk and uncertainty tolerances. First three of these are negative questions related to risk and uncertainty and last three are positive ones related to risk and uncertainty.

\section{Analysis of the Data}

SPSS 20.0 package program was used in the analysis. In conducted reliability analysis, Cronbach's Alpha internal consistency coefficient for the subscales knowledge and accomplishment of sport motivation is found as $0.89 ; 0.76$ for the subscale experiencing stimulation and 0.92 for the complete of the scale intrinsic motivation.

Factor analysis was used for the questions of risk and uncertainty tolerances and as a result of the analysis, two sub factors. KMO rate was found as 0.68 . Cronbach's Alpha internal consistency coefficients of the factors were found as 0.55 and 0.70 and analyses were maintained through the factor with higher internal consistency coefficient.

(Table, 1). Obtained data was analyzed by using frequency analysis, T-test, crosstabs, Chi-square, One-way Anova and Tukey tests. Results were evaluated at 0.05 significance level.

Table 1. Factor Analysis, Chi-Square and Cronbach's Alpha Values of Perception of Risk and Uncertainty

\begin{tabular}{lcccc}
\hline & $\begin{array}{c}\text { Chi- } \\
\text { Square }\end{array}$ & Factor1 & Factor2 & Cronbach's Alpha \\
\hline Risk 1 &, 118 & & & \\
Risk 2 &, 000 & &, 824 & 0,55 \\
\hline Risk 3 &, 000 &, 834 & \\
\hline Risk 4 &, 000 &, 793 & & 0,65 \\
\hline Risk 5 &, 000 &, 814 & & 0,70 \\
\hline Risk 6 &, 000 &, 761 & & \\
\hline
\end{tabular}

\section{FINDINGS}

Findings below were obtained as a result of conducted in the research: 
www.sstbdergisi.com

International Refereed Academic Journal of Sports, Health and Medical Sciences October / November / December - Autumn Winter Period Issue: 21 Year: 2016

GEL CODE: A23-I15-J11-J64-M5-M10-M12-M19-M31-P36 ID:310 K:398

ISSN Print: 2146-8508 Online 2147-1711

(ISO 9001-2008 Document No: 12879 \& ISO 14001-2004 Document No: 12880)

(TRADEMARK)

(2015/04315- 2015-GE-18972)

Table 2. Crosstab by Age and Gender

\begin{tabular}{lccccc}
\hline & & Gender & & Total \\
\hline \multirow{3}{*}{ Age } & Female & Male & \\
& Age $17-20$ & 23 & 18 & 41 \\
\cline { 2 - 5 } & Age $21-24$ & 61 & 68 & 129 \\
\cline { 2 - 5 } & Age $25-28$ & 13 & 35 & 48 \\
\hline \multirow{2}{*}{ Total } & & $\mathbf{9 7}$ & $\mathbf{1 2 1}$ & $\mathbf{2 1 8}$ \\
\hline
\end{tabular}

Table 3. Crosstab by Age and Grade

\begin{tabular}{|c|c|c|c|c|c|c|}
\hline & & \multicolumn{4}{|c|}{ Grade } & \multirow[t]{2}{*}{ Total } \\
\hline & & $1^{\text {st }}$ Grade & $2^{\text {nd }}$ Grade & $3^{\text {rd }}$ Grade & $4^{\text {th }}$ Grade & \\
\hline & Age $17-20$ & 15 & 21 & 3 & 2 & 41 \\
\hline \multirow[t]{2}{*}{ Age } & Age $21-24$ & 8 & 46 & 51 & 24 & 129 \\
\hline & Age $25-28$ & 2 & 15 & 15 & 16 & 48 \\
\hline Total & & 25 & 82 & 69 & 42 & 218 \\
\hline
\end{tabular}

Table 4. Frequency Analysis of Personality and Demographic Characteristics

\begin{tabular}{|c|c|c|c|c|c|c|c|}
\hline & Parameters & Frequency & Percent & & Parameters & Frequency & Percent \\
\hline \multirow{3}{*}{ Gender } & Female & 97 & 44,5 & \multirow{5}{*}{ Grade } & $1^{\text {st }}$ Grade & 25 & 11,5 \\
\hline & Male & 121 & 55,5 & & $2^{\text {nd }}$ Grade & 82 & 37,6 \\
\hline & Total & 218 & 100,0 & & $3^{\text {rd }}$ Grade & 69 & 31,7 \\
\hline \multirow{7}{*}{ Age } & Age 17-20 & 41 & 18,8 & & $4^{\text {th }}$ Grade & 42 & 19,3 \\
\hline & Age 21-24 & 129 & 59,2 & & Total & 218 & 100,0 \\
\hline & Age $25-28$ & 48 & 22,0 & \multirow{5}{*}{ Department } & Teaching & 45 & 20,6 \\
\hline & Total & 218 & 100.0 & & Coaching & 78 & 35,8 \\
\hline & & & & & Recreation & 37 & 17,0 \\
\hline & & & & & $\begin{array}{l}\text { Sport } \\
\text { Management }\end{array}$ & 58 & 26,6 \\
\hline & & & & & Total & 218 & 100,0 \\
\hline
\end{tabular}




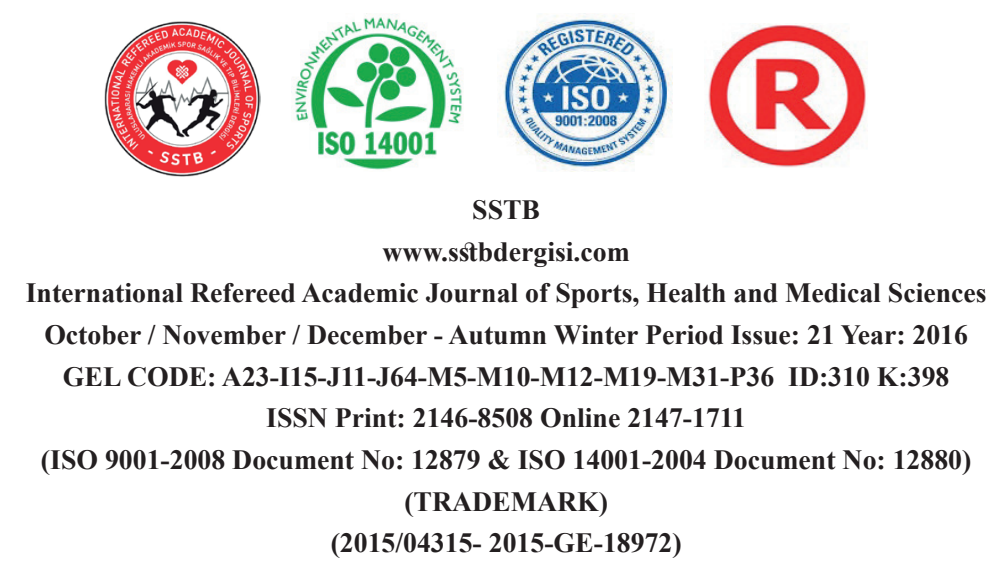

As tables 1-4 are examined, these findings were obtained. $\mathrm{N}=218$ and there are $97 \mathrm{fe}-$ male participants and 121 male participants. $59.2 \%$ of participants are 68 males and 61 females in 21-24 age group; $22.0 \%$ of participants are 35 males and 13 females in 2528 age group; $18.8 \%$ of participants are 18 males and 23 females in 17-20 age group.
$37.6 \% 2^{\text {nd }}$ grade, $31.7 \% 3^{\text {rd }}$ grade, $19.3 \% 4^{\text {th }}$ grade, $11.5 \% 1^{\text {st }}$ grade. Participants are distributed among $2^{\text {nd }}$ and $3^{\text {rd }}$ grades. Students are receiving their educations in the department of coaching (35.8\%), in sport management $(26.6 \%)$, in physical education and sport teaching (20.6\%) and in recreation (17.0\%).

Table 5. Correlation Analysis of Sport Motivation and Perception of Risk and Uncertainty

\begin{tabular}{llccc}
\hline & Sport Motivation & $\begin{array}{c}\text { Experiencing } \\
\text { Stimulation }\end{array}$ & $\begin{array}{c}\text { Knowledge and } \\
\text { Accomplishment }\end{array}$ \\
\hline Perception & $\begin{array}{l}\text { Pearson } \\
\text { of Risk and }\end{array}$ &, $547^{* *}$ &, $490^{* *}$ &, $545^{* *}$ \\
\cline { 2 - 5 } \begin{tabular}{l} 
Correlation \\
\cline { 2 - 5 }
\end{tabular} & Sig. (2-tailed) &, 000 &, 000 &, 000 \\
\hline & $\mathrm{N}$ & 218 & 218 & 218 \\
\hline
\end{tabular}

Whether there is a relationship between intrinsic relationship in sports and individuals' perception of risk and uncertainty was examined by correlation analysis method along with whole of sport motivation scale and its subscales (Table 5). Correlation coefficient is a value which changes between -1 and +1 and measure the extent of linear relationship between two variables. A value close to -1 means a strong negative linear correlation and a value close to +1 indicates a strong positive linear correlation (Altunışık et all, 2010). In the analysis, these were determined, $\mathrm{r}=0.547$, $\mathrm{r}=0.490, \mathrm{r}=0.545$. Therefore, these were concluded that there is a positive, moderate and linear relationship between attitudes towards intrinsic motivation in sports and individuals" perception of risk and uncertainty, there is a positive, moderate and linear relationship between intrinsic motivation and individuals' perception of risk and uncertainty and between the subscale experiencing stimulation and the subscales knowledge and accomplishment. Thus, the hypothesis H1: "There is a correlation between intrinsic motivation in sports and individuals' perception of risk and uncertainty." is accepted. 

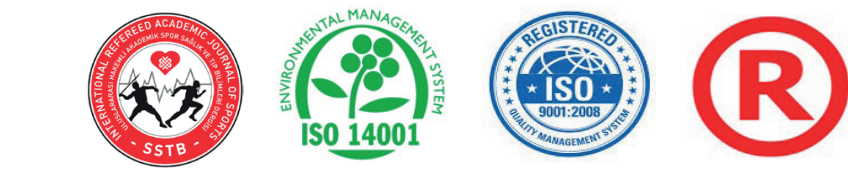

SSTB

www.sstbdergisi.com

International Refereed Academic Journal of Sports, Health and Medical Sciences

October / November / December - Autumn Winter Period Issue: 21 Year: 2016

GEL CODE: A23-I15-J11-J64-M5-M10-M12-M19-M31-P36 ID:310 K:398

ISSN Print: 2146-8508 Online 2147-1711

(ISO 9001-2008 Document No: 12879 \& ISO 14001-2004 Document No: 12880)

(TRADEMARK)

(2015/04315- 2015-GE-18972)

Table 6. Regression Analysis Measuring the Effect of Sport Motivation on Perception of Risk and Uncertainty

\begin{tabular}{|c|c|c|c|c|c|c|c|c|}
\hline Variables & B & $\mathbf{t}$ & Sig. & $\mathbf{R}$ & $\mathbf{R}^{2}$ & $\mathbf{F}$ & Sig.F & Result \\
\hline Fixed & 1,413 & 5,335 &, 000 & & & & & \\
\hline \multirow[t]{2}{*}{ Sport Motivation } & ,611 & 9,592 &, 000 & & & & & Accepted \\
\hline & & & & ,547 & ,299 & 92,007 &, 000 & \\
\hline
\end{tabular}

As seen in table 6 according to the results of the regression analysis done in order to find out whether there is any effect of intrinsic motivation on in sports on individuals' perception of risk and uncertainty, it has been seen detected that intrinsic motivation in sports affects has effect on individuals' perception of risk and uncertainty $(p=0.000$ and $p<0.05)$ and the regression model which expresses this effect has been developed as $\mathrm{Y} 1_{\text {(perception of }}$ risk and uncertainty) $=1,413+0,611_{\text {(Sport Motivation) }}$.

Therefore, the hypothesis H2: "Intrinsic motivation in sports affects has effect on individuals' perception of risk and uncertainty." is accepted affects individuals' perception of risk and uncertainty.

\section{DISCUSSION and RESULTS}

The results below have been gained in the research which was conducted by participation of 218 students in total chosen by sample random sampling method among the students of School of Physical Education and Sports of Erciyes University who involve sports in their daily lives and which was conducted to investigate whether there is a relationship between individuals' attitudes towards their perceptions of risk and uncertainty in their daily lives, who are intrinsically motivated in sports;

$59.2 \%$ of participants are 68 males and 61 females in 21-24 age group;. $22.0 \%$ of participants are 35 men and 13 females in 2528 age group; $18.8 \%$ of participants are 18 males and 23 females in 17-20 age group. $37.6 \% 2^{\text {nd }}$ grade, $31.7 \% 3^{\text {rd }}$ grade, $19.3 \% 4^{\text {th }}$ grade, $11.5 \% 1^{\text {st }}$ grade. Participants are distributed among $2^{\text {nd }}$ and $3^{\text {rd }}$ grades. Students are receiving their educations in the department of coaching $(35.8 \%)$, in sport management $(26.6 \%)$, in physical education and sport teaching (20.6\%) and in recreation (17.0\%).

Whether there is a relationship between intrinsic relationship in sports and individuals' perception of risk and uncertainty was examined by correlation analysis method along with whole of sport motivation scale and its 


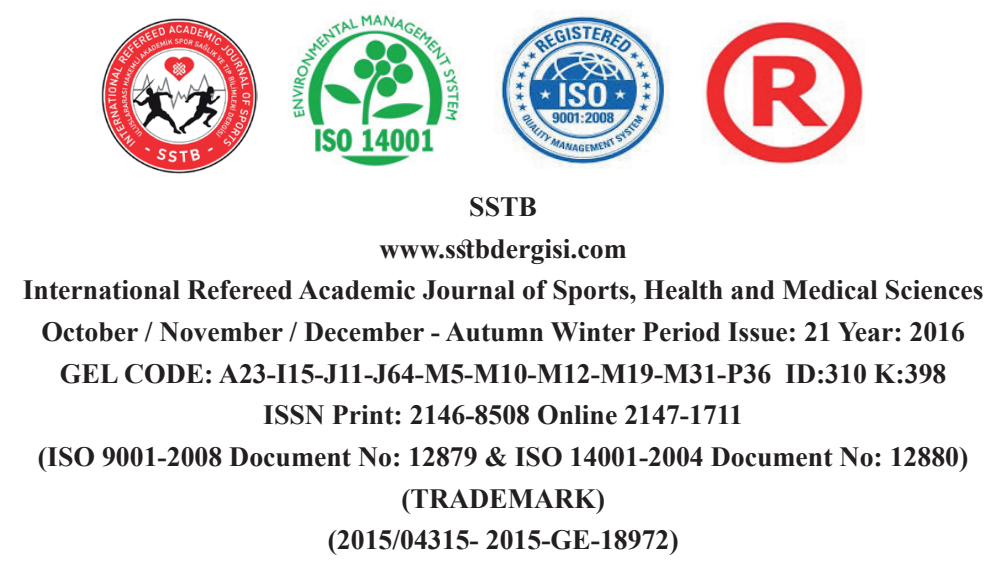

subscales. In the analysis, these were determined, $r=0.547, r=0.490, r=0.545$. Therefore, these were concluded that there is a positive, moderate and linear relationship between attitudes towards intrinsic motivation in sports and individuals" perception of risk and uncertainty, there is a positive, moderate and linear relationship between intrinsic motivation and individuals' perception of risk and uncertainty and between the subscale experiencing stimulation and the subscales knowledge and accomplishment. Thus, the hypothesis H1: "There is a correlation between intrinsic motivation in sports and individuals' perception of risk and uncertainty." is accepted.

As seen in Table VI, according to the results of the regression analysis done in order to find out whether there is any effect of intrinsic motivation on in sports on individuals' perception of risk and uncertainty, it has been detected that intrinsic motivation in sports affects individuals' perception of risk and uncertainty $(p=0.000$ and $p<0.05)$ and the regression model which expresses this effect has been developed as $\mathrm{Y} 1_{\text {(perception of risk and uncerta- }}$ ${ }_{\text {inty) }}=1,413+0,611_{\text {(Sport Motivation) }}$. Therefore, the hypothesis H2: "Intrinsic motivation in sports affects has effect on individuals' perception of risk and uncertainty." is accepted.

According to Cox (1998), intrinsic motivation is the same with motive to accomplish. There is no close relationship between accomp- lishment and tolerance for uncertainty and risk taking. Tolerance for uncertainty which is one of the most important characteristics of entrepreneur individuals can be defined as the ability to react positively to uncertain situations (Erdem, 2001, p.58). According to Tabak et al. (2010), individuals with focus of internal audit have higher tendency to tolerance for uncertainty. Individuals with focus of internal audit have the belief that they can affect the events occurring around them. Therefore, these individuals gives more importance to success or failure (Tabak et al., 2010: 159). Basım and Şeşen (2007), Spector and O'connell (1994) reached similar results in their works. This verifies our hypotheses indirectly (Basım and Şeşen 2007: 117) Also, in the studies done by Slanger and Rudestam (1997) it was concluded that, as risk taking levels of individuals who actively are in sports are evaluated, they have higher scores of risk taking than individuals who do not do sports have (Slanger and Rudestam, 1997: 368) This conclusion is similar to our study. The concepts risk and motivation have been mentioned separately in various studies but they have not been in the same frame so much. This research is also important because of relating and evaluating these two concepts in the same frame. It was concluded that there is a positive, moderate and linear correlation between individuals' perception of risk and uncertainty who are motivated intrinsically 


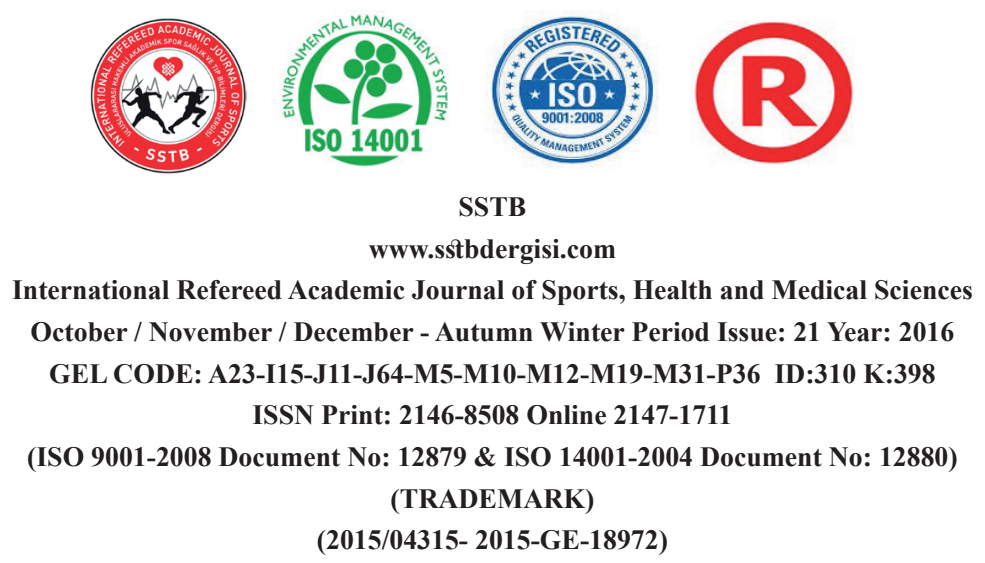

and intrinsic motivation in sports with its subscales affects individuals' perception of risk and uncertainty.

\section{REFERENCES}

AKTAŞ, I., \& ERHAN, S. E., (2015). Investigation of Self-Respect and Risk-Taking Level of Individuals Doing Sport or not (The Example of Erzurum Province)

ALTUNIŞIK, R., COŞKUN, R., BAYRAKTAROĞLU, S., YILDIRIM, E., (2010).

Research Methods in Social Sciences (With SPSS) $\left(6^{\text {th }}\right.$ Ed.). Sakarya: Sakarya Publishing

BAKKER, F.C., WHITING H.T.A., \& VAN DER, BRUG, H., (1990). Sport Psychology: Concepts And Applications, New York, John Wiley And Sons, 1990

BASIM, N., \& ŞEŞEN, H., (2007). Transformation to A Learning Organization: A Comparative Study On Textile Industry In Turkey. Economy, Management and Finance 21 (251): 114-122

BAŞER, E., (1998). Applied Sport Psychology. Bağırgan Publishing, Ankara

BOZKURT, V., BAŞTÜRK, Ş., (2009). Risk and Uncertainty Perceptions of SME Entrepreneurs: A Case of Bursa P r o vince. Ankara University Sbf Journal, 64(02), 043-074
COX, R.H., (1998). Sport Psychology: Concepts and Applications. 4th Ed.The Mcgraw-Hill, 236-271

DANIŞMAN, I. H. A., (2011). The Research of the Effect on Anxiety Level of the Motivational Tendency of the Students Who Do Individual and Team Sports. Gazi University. Institute of Health Sciences, Master's Thesis

ERDEM, M., (2008). Development of Sport Motivation Scale at American Football Players. Master Ankara: Ankara University

ERDEM, F., (2001). A Cultural Approach Towards Risk Propensity and Tolerance for Ambiguity of Entrepreneurs. A kde niz University Faculty of Economics \& Administrative Sciences Faculty Journal. $1(2), 43-61$

DECI, E. L., \& RYAN, R. M., (2000). The 'What' and 'Why' Of Goal Pursuits: Human Needs And The Self- Determination Of Behavior. Psychological Inquiry, 11(4), 227-268

EREN, E., (2015). Psychology of Organizational Behavior and Management. İstanbul: Beta Publishing

ERSÖZ, G., ÖZTÜRK, M., KILINÇ, F., KOŞKAN, Ö., ÇETINKAYA, E., (2014). Examining Motivational Orientation 


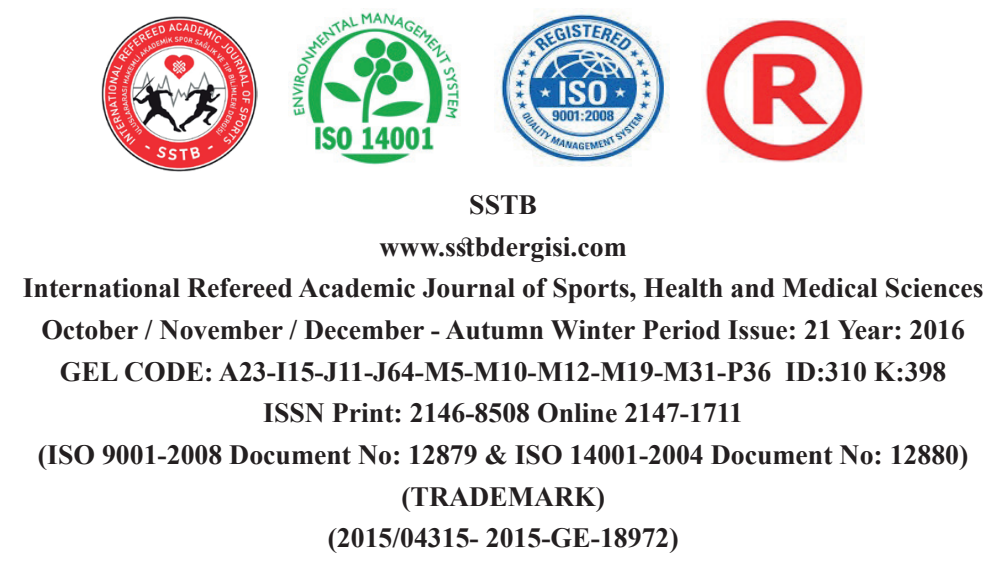

of Athletes in terms of Some Variables. CBU Journal of Physical Education and Sport Sciences, 7(1): 15-26

FINUCANE, M.L., ALHAKAMI, A., SLOVIC, P., JOHNSON, S.M., (2000). The Affect Heuristic in Judgments of Risks and Benefits, Journal of Behavioral Decision Making, 13: 1-17

FUREDI, F, (2001). Culture of Fear. İstanbul: Ayrıntı Publishing

FRANKEN, R., (1994). Human Motivation (3rd Ed.). Pacific Grove, Ca: Brooks/ Cole Publishing Co

KAZAK, ÇETINKALP, F. Z., (2009). An Evaluation of Self-Determination Theory and Achievement Goal Theory in Sports. Ege University, Institute of Health Sciences, Doctoral Thesis, İzmir

$K A Z A K, Z$., (2004). A Study on Reliability and Validity of "The Sport Motivation Scale -Sms-" For Turkish Athletes. Journal of Sport Sciences, 15(4), 191-206

KOTLER, P., ARMSTRONG, G., SOUNDERS, J., \& WANG, V. (1999). Principles of Marketing, Second European Edition, Prentice Hall.

MUMCU, H. E., (2011). Effect of Personalities of Athletes Doing Sports Requiring Open and Closed Skills on Their Motiva- tion, Gazi University. Institute of Health Sciences, Master's Thesis

SITKIN, S.B., PAOLO, A. L., (1992). Reconceptualizing the Determinants of Risk Behavior. Academy of Management Review, 17(1), 19-38.

SLANGER, E., RUDESTAM, K.E., (1997). Motivation and Disinhibition in High Risk Sports: Sensation Seeking and SelfEfficacy, Journal of Research In Personality, 31: 355-374

SPECTOR, P. E., (1982). Behavior in Organizations as a Function of Employee Locus of Control. Psychological Bulletin. 91: 482-497.

TABAK, A. T., ERKUŞ, A. T., MEYDAN, H. T., (2010). The Relationship Between Locus of Control and Innovative Individual Behaviors: Mediating Effect of Tolerance for Ambiguity and Risk Taking On Innovativeness. Anadolu University Journal of Social Sciences, 10(1), 159

TOROS, Z., (2000). A Study on Reliability and Validity of "The Sport Motivation Scale-Sms-" For Turkish A t h letes. VI. International Sports Science Congress. Ankara: Hacettepe University November 3-5

ÖZER, L. T., GÜLPINAR, S. T., (2005). Risks Perceived by Customers in Service 
Sector:A Survey in Airline Industry. Gazi University Journal of Commerce \& Tourism Education Faculty, (1),48-63

\section{VALLERAND, R.J., DECI, E.L, RYAN,} R.M., (1987). Intrinsic Motivation in Sport. In K. Pandolf (Ed.), Exercise and Sport Science Reviews (Vol. 15, Pp. 389425). New York. Macmillan

VALLERAND, R.J., BISSONNETTE, R., (1992). Intrinsic, Extrinsic, and Amotivational Styles As Predictors Of Behavior: A Prospective Study. Journal of Personality

VALLERAND, R., LOSIER, G., (1999). An Integrative Analysis of Intrinsic and Ext- rinsic Motivation in Sport. Journal Of Applied Sport Psychology

WANG, C.K.J., BIDDLE, S.J.H., (2004). Intrinsic Motivation Towards Sports In Singaporean Students: The Role Of Sport Ability Beliefs. Journal of Health Psychology, $8,515-523$

WILLETT, A. M., (1971). The Economic Theory of Risk and Insurance, Huebner Foundation Studies, New York, 471-601

YILMAZ, U., (2005). Risk Management in Aviation and Examination of Risk Areas in Civil Aviation Transport, Master's Thesis, Gazi University, Institute of Social Sciences, Ankara 